\title{
Monodisperse Mesoporous Carbon Nanoparticles from Polymer/Silica Self-Aggregates and their Electrocatalytic Activities
}

Xiaoxi Huang, ${ }^{\dagger}$ Li-Jing Zhou, ${ }^{\S}$ Damien Voiry, ${ }^{\|}$Manish Chhowalla, ${ }^{\|}$Xiaoxin Zou, ${ }^{*}{ }^{\S}$ and Tewodros Asefa $^{*}, \dagger, \dagger$

${ }^{\dagger}$ Department of Chemistry and Chemical Biology, Rutgers, The State University of New Jersey, Piscataway, New Jersey, 08854, United States.

$\S$ State Key Laboratory of Inorganic Synthesis and Preparative Chemistry, International Joint Research Laboratory of Nano-Micro Architecture Chemistry, College of Chemistry, Jilin University, Changchun 130012, China.

" Department of Materials Science and Engineering, Rutgers, The State University of New Jersey, Piscataway, New Jersey, 08854, United States.

\$Department of Chemical and Biochemical Engineering, Rutgers, The State University of New Jersey, Piscataway, New Jersey, 08854, United States.

* Corresponding Authors: E-mails: (XZ)xxzou@jlu.edu.cn; (TA) tasefa@rci.rutgers.edu 
Table S1. Comparisons of the amounts of reactants as well as the synthetic conditions employed to synthesize the different carbon nanomaterials and the corresponding control carbon materials studied in the work.

\begin{tabular}{|c|c|c|c|c|c|c|c|}
\hline No. & $\begin{array}{l}\text { Amount } \\
\text { of } \\
\text { aniline }\end{array}$ & $\begin{array}{l}\text { Amount of } \\
\text { colloidal } \\
\text { silica }\end{array}$ & $\begin{array}{l}\text { Amount } \\
\text { of } \\
\text { solvent }\end{array}$ & Amount of oxidant & $\begin{array}{c}\text { Name of } \\
\text { polymer-silica } \\
\text { product }\end{array}$ & $\begin{array}{c}\text { Pyrolysis } \\
\text { temperature } \\
\left({ }^{\circ} \mathrm{C}\right)\end{array}$ & $\begin{array}{l}\text { Name of final } \\
\text { carbon product }\end{array}$ \\
\hline 1 & \multirow{7}{*}{$1 \mathrm{~mL}$} & \multirow{5}{*}{$11.5 \mathrm{~mL}$} & \multirow{4}{*}{$\begin{array}{c}60 \mathrm{~mL}, \\
1 \mathrm{M} \mathrm{HCl}\end{array}$} & \multirow{6}{*}{$\begin{array}{l}2.5 \mathrm{~g} \text { Ammonium } \\
\text { persulfate in } 12 \mathrm{~mL} \text {, } \\
1 \mathrm{M} \mathrm{HCl}\end{array}$} & \multirow{4}{*}{$\mathrm{PANI}_{-\mathrm{SiO}_{2}}$} & 700 & PAMC-700 \\
\hline 2 & & & & & & 800 & PAMC-800 \\
\hline 3 & & & & & & 900 & PAMC-900 \\
\hline 4 & & & & & & 1000 & PAMC-1000 \\
\hline 5 & & & $\begin{array}{c}15 \mathrm{~mL}, \\
1 \mathrm{M} \mathrm{HCl}\end{array}$ & & $\mathrm{PANI}_{-\mathrm{SiO}_{2}-15}$ & 900 & PAMC-900-15 \\
\hline 6 & & None & $\begin{array}{c}60 \mathrm{~mL}, \\
1 \mathrm{M} \mathrm{HCl}\end{array}$ & & PANI & 900 & PANC-900 \\
\hline 7 & & $11.5 \mathrm{~mL}$ & $\begin{array}{l}60 \mathrm{~mL} \\
\text { water }\end{array}$ & $\begin{array}{l}2.5 \mathrm{~g} \text { Ammonium } \\
\text { persulfate in } 12 \mathrm{~mL} \\
\text { water }\end{array}$ & $\mathrm{PANI}-\mathrm{SiO}_{2}-\mathrm{H}_{2} \mathrm{O}$ & 900 & PAMC- $900-\mathrm{H}_{2} \mathrm{O}$ \\
\hline
\end{tabular}

Table S2. Comparisons of the BET surface areas, pore volumes, and average pore diameters of the different carbon nanomaterials and control carbon materials synthesized for the studies.

\begin{tabular}{|c|c|c|c|}
\hline Carbon Material & $\begin{array}{c}\text { BET surface area } \\
\left(\mathbf{m}^{\mathbf{2}} \mathbf{g}\right)\end{array}$ & Pore volume $\mathbf{( \mathbf { c m } ^ { 3 } \mathbf { g } )}$ & Average pore size (nm) \\
\hline PAMC-700 & 554 & 0.91 & 14.8 \\
\hline PAMC-800 & 593 & 0.99 & 14.4 \\
\hline PAMC-900 & 652 & 1.21 & 13.4 \\
\hline PAMC-1000 & 185 & 0.37 & 15.9 \\
\hline PANC-900 & 18 & 0.70 & -- \\
\hline (A control material) & & & \\
\hline
\end{tabular}




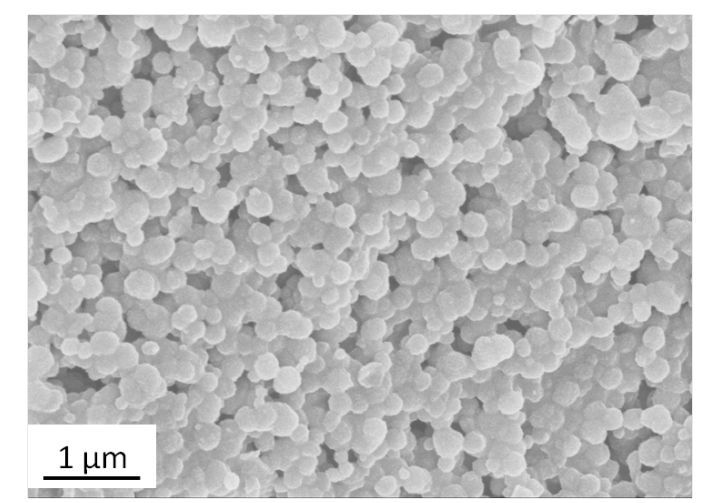

Figure S1. SEM image of PAMC-900-15.
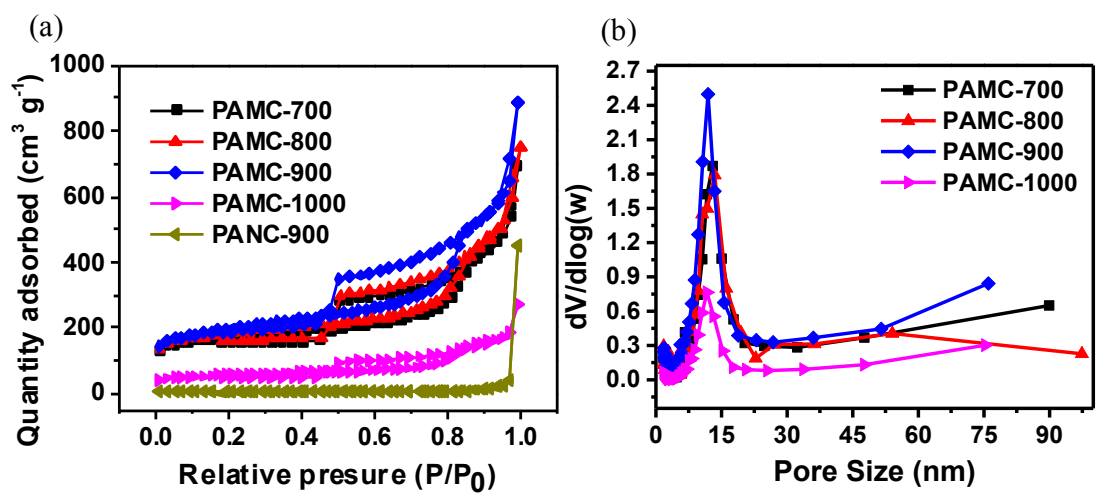

Figure S2. (a) Nitrogen adsorption/desorption isotherms of the PAMC materials obtained using different pyrolysis temperatures: PAMC-700, PAMC-800, PAMC-900, PAMC-1000, and PANC-900. (Note that PANC-900 is the control material synthesized from PANI without using silica nanoparticles as templates). (b) BJH pore size distribution curves of PAMC-700, PAMC-800, PAMC-900, and PAMC-1000.
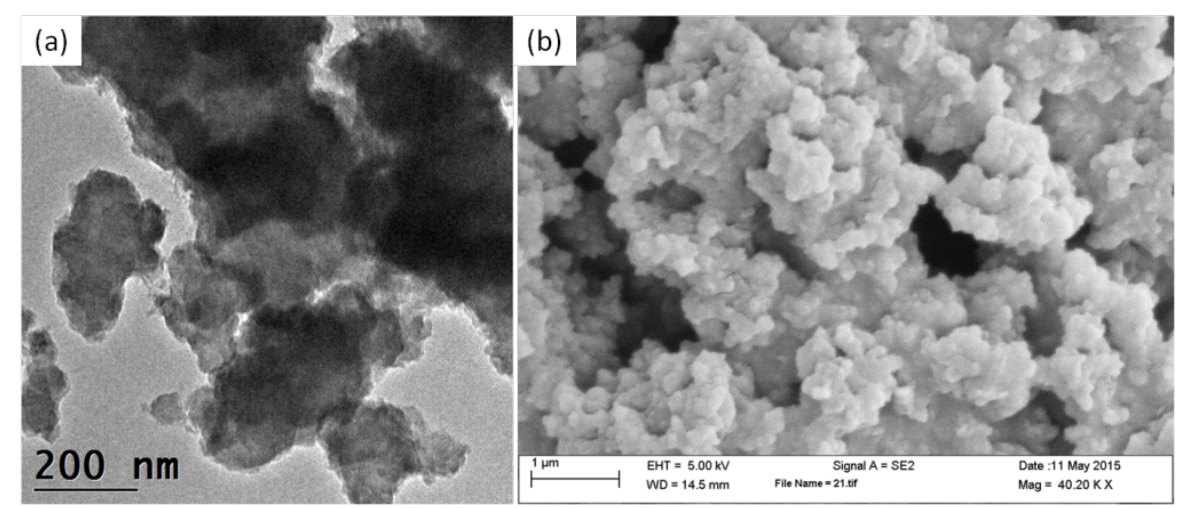

Figure S3. (a) TEM and (b) SEM images of PANC-900 (the control material synthesized from PANI without using silica nanoparticles as templates). 


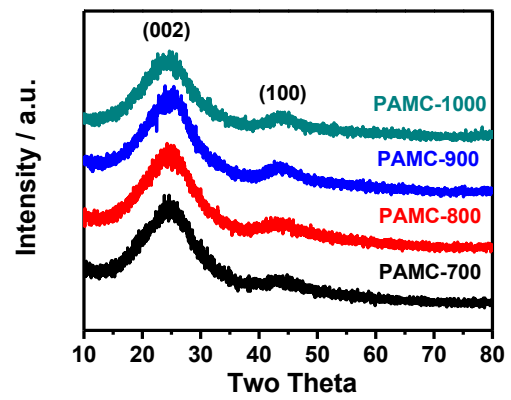

Figure S4. XRD patterns of PAMC-700, PAMC-800, PAMC-900, and PAMC-1000.

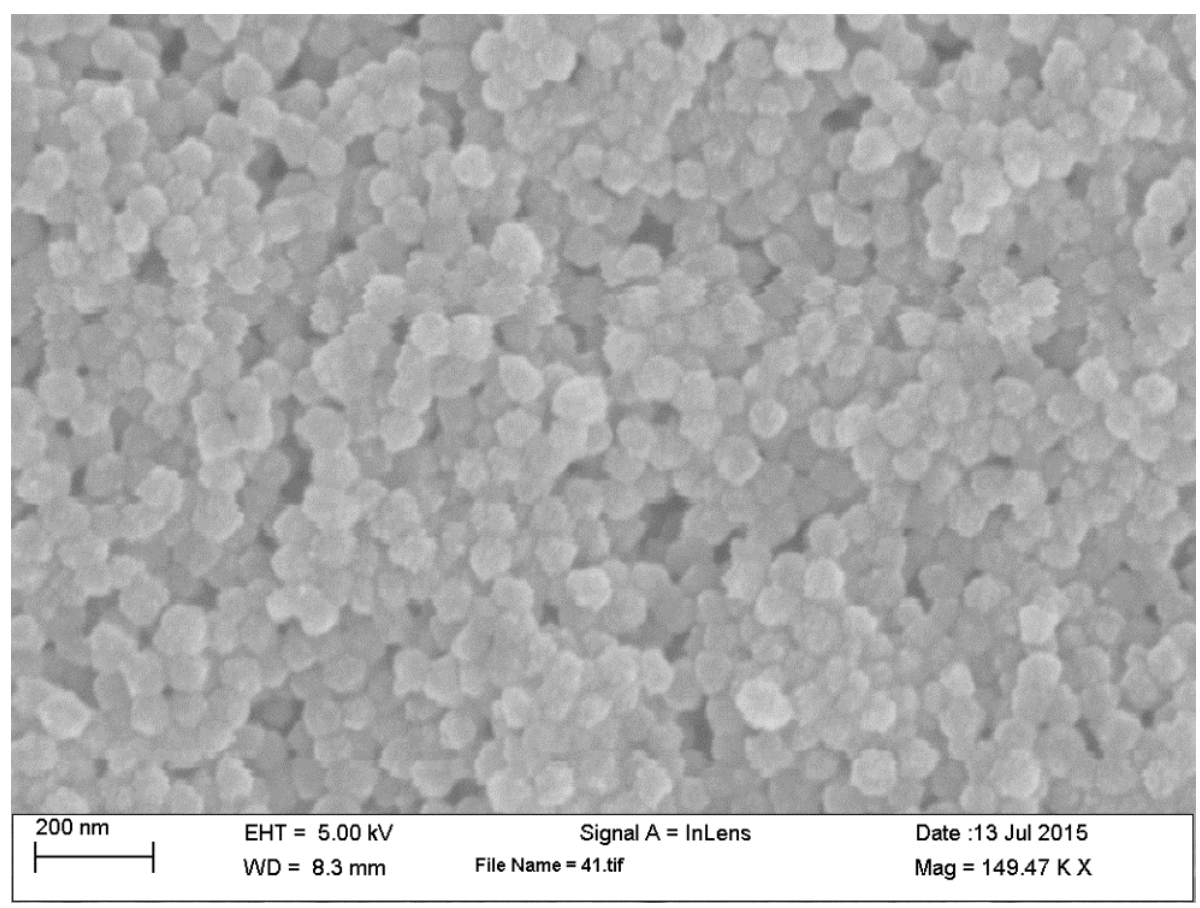

Figure S5. SEM image of polypyrrole (PPY)-derived mesoporous carbon material. The material is synthesized using PPY as precursor and silica nanoparticles as templates. First, $\mathrm{PPY} /$ colloidal $\mathrm{SiO}_{2}$ composite material was synthesized. The material was then pyrolyzed at $900{ }^{\circ} \mathrm{C}$, and the $\mathrm{SiO}_{2}$ nanoparticles in the pyrolyzed material were etched. 


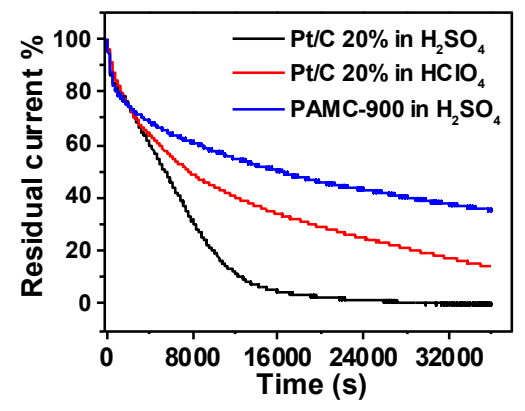

Figure S6. Chronoamperometric curves showing the percentage of residual current versus time in the HPRR over PAMC-900 or Pt/C (20 wt.\%) for $30 \mathrm{mM} \mathrm{H}_{2} \mathrm{O}_{2}$ in $0.1 \mathrm{M} \mathrm{H}_{2} \mathrm{SO}_{4}$ solution, and over $\mathrm{Pt} / \mathrm{C}\left(20\right.$ wt.\%) for $30 \mathrm{mM} \mathrm{H}_{2} \mathrm{O}_{2}$ in $0.1 \mathrm{M} \mathrm{HClO}_{4}$ at a potential of $0.5 \mathrm{~V} v s$. RHE.

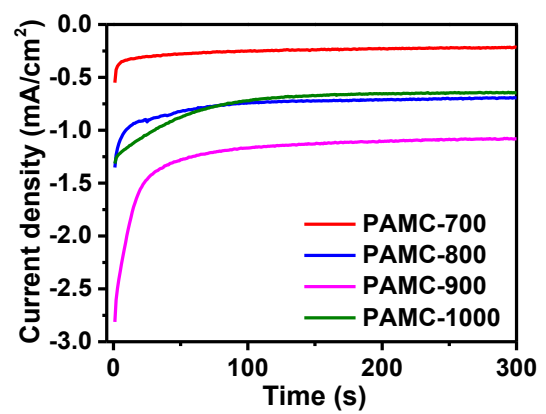

Figure S7. Comparison of the chronoamperometric curves of HPRR in $0.1 \mathrm{M} \mathrm{H}_{2} \mathrm{SO}_{4}$ solution at 0.5 $\mathrm{V} v s$. RHE over the different PAMC materials.

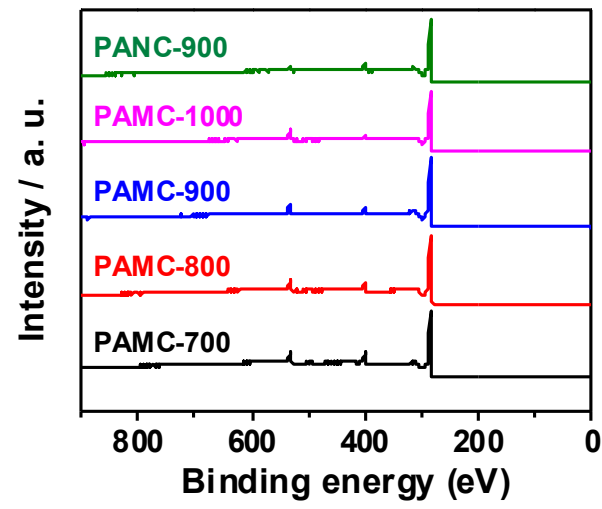

Figure S8. XPS survey spectra of PANC-900, PAMC-700, PAMC-800, PAMC-900, and PAMC-1000. 

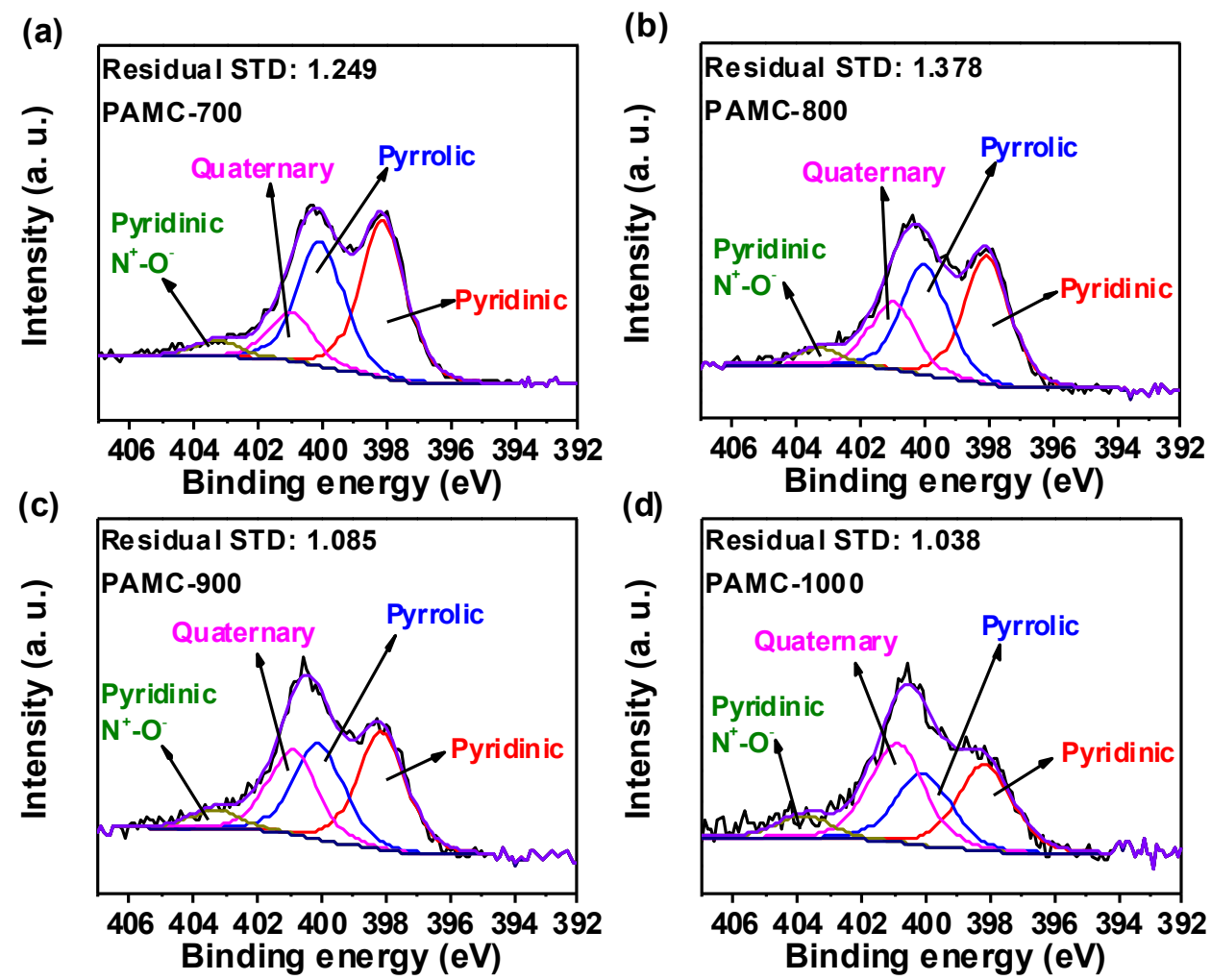

Figure S9. High-resolution XPS spectra of the N1s peak of PAMC-700 (a), PAMC-800 (b), PAMC-900 (c), and PAMC-1000 (d). 

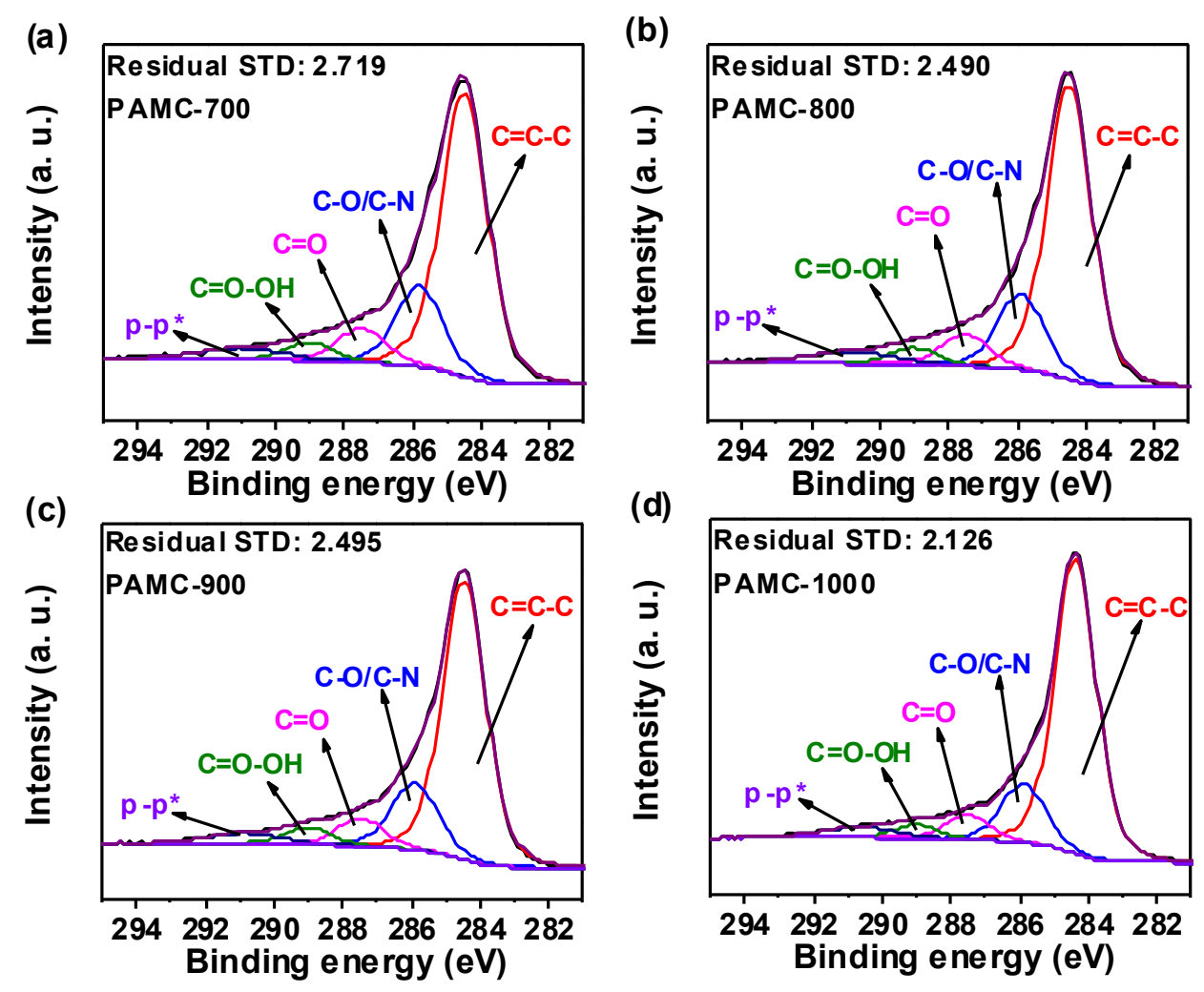

Figure S10. High-resolution XPS spectra of the C1s peak of PAMC-700 (a), PAMC-800 (b), PAMC-900 (c), and PAMC-1000 (d). 

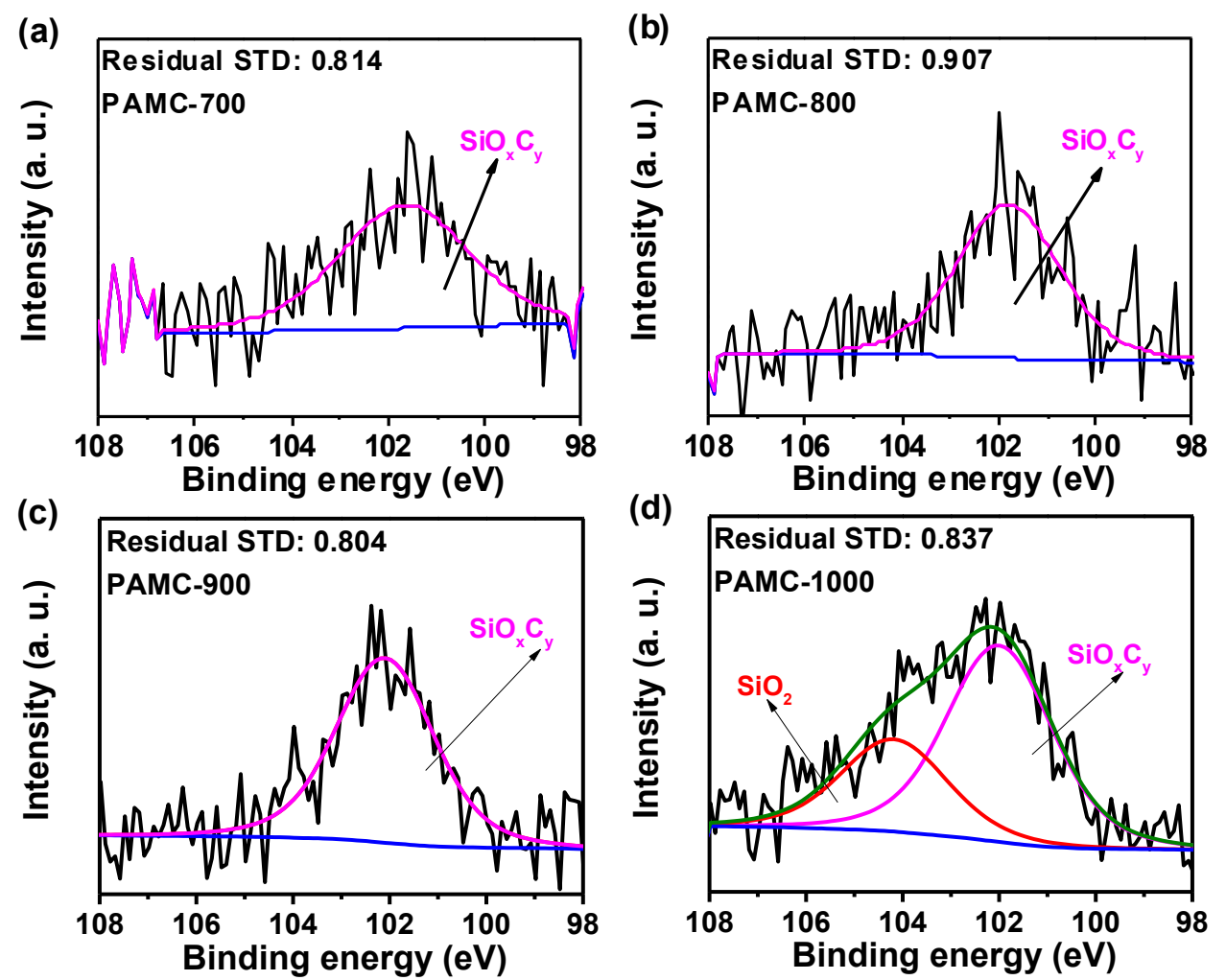

Figure S11. High-resolution XPS spectra of the Si2p peak of PAMC-700 (a), PAMC-800 (b), PAMC-900 (c), and PAMC-1000 (d).

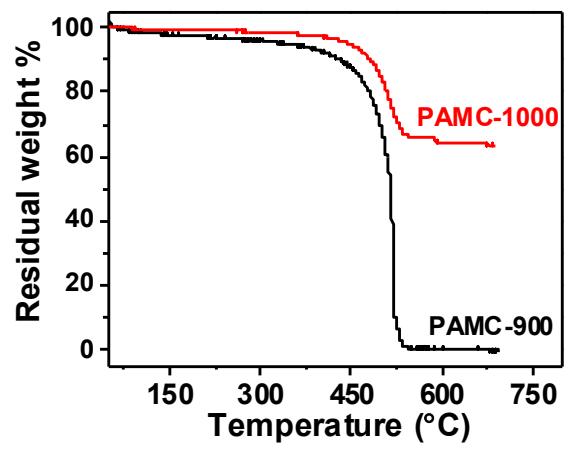

Figure S12. TGA curves obtained in air of PAMC-1000 and PAMC-900. 


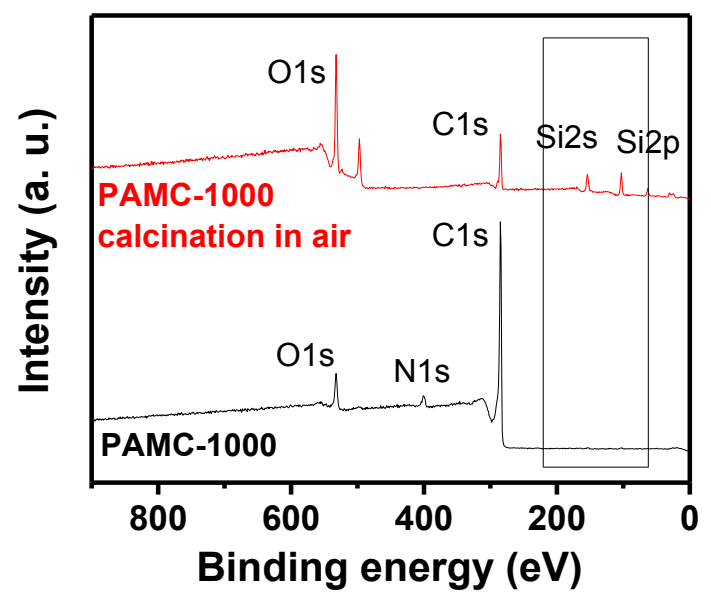

Figure S13. XPS survey spectra of PAMC-1000, as prepared (shown in black) and after further treatment in air at $900{ }^{\circ} \mathrm{C}$ (shown in red).
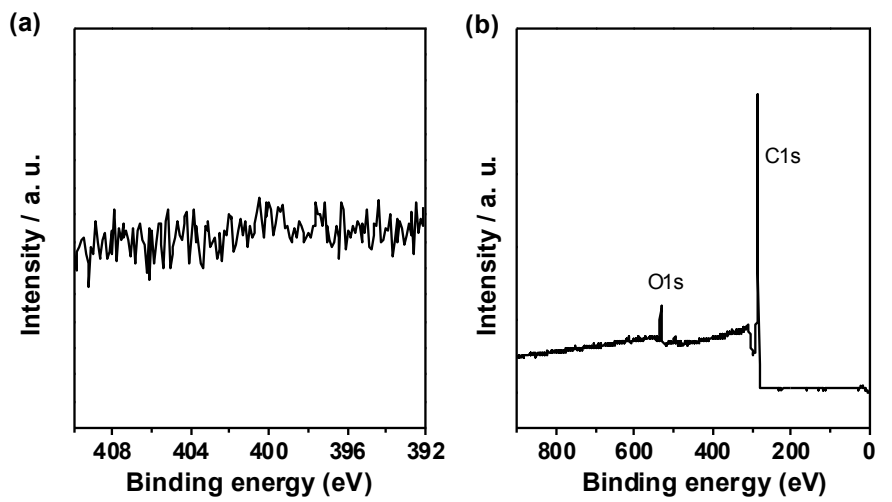

Figure S14. High-resolution XPS spectra of N1s (a) and XPS survey spectra (b) of FAMC-900 sample. As expected, the N1s region in (a) shows no peaks.

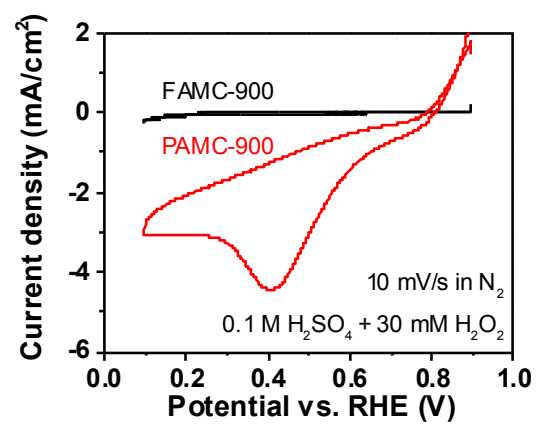

Figure S15. CV curves recorded for $30 \mathrm{mM} \mathrm{H}_{2} \mathrm{O}_{2}$ in $0.1 \mathrm{M} \mathrm{H}_{2} \mathrm{SO}_{4}$ over FAMC-900 and PAMC-900. 


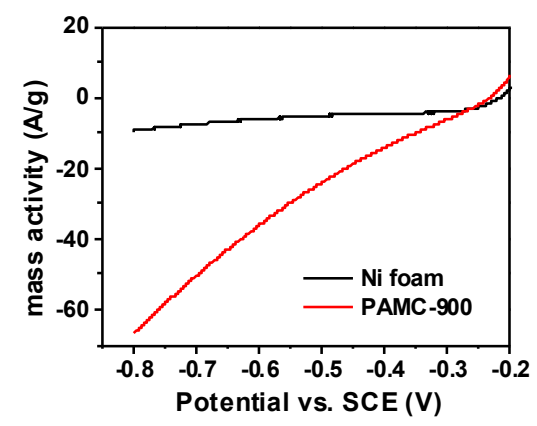

Figure S16. Linear sweep voltammograms (LSV) in $3 \mathrm{M} \mathrm{KOH}$ solution containing $0.6 \mathrm{M} \mathrm{H}_{2} \mathrm{O}_{2}$ over a Ni foam electrode loaded with PAMC-900 $\left(1 \mathrm{mg} / \mathrm{cm}^{2}\right)$ and a bare $\mathrm{Ni}$ foam electrode (control sample). In addition, the electrocatalytic activity of the materials toward HPRR in $3 \mathrm{M} \mathrm{KOH}$ with $0.6 \mathrm{M} \mathrm{H}_{2} \mathrm{O}_{2}$ was investigated by loading PAMC-900 on a nickel foam electrode. As shown in this figure, PAMC-900 showed a much stronger activity for HPRR compared with bare nickel foam. 
Table S3. Comparisons of the catalytic activity of PAMC toward HPRR with selected catalysts from the literature the same reaction. ${ }^{\text {a }}$

\begin{tabular}{|c|c|c|c|c|c|c|c|}
\hline Catalyst/Electrode & Electrolyte & $\begin{array}{c}\text { Sweep } \\
\text { rate } \\
(\mathrm{mV} / \mathrm{s})\end{array}$ & $\begin{array}{l}\text { Conc. } \\
\mathrm{H}_{2} \mathrm{O}_{2} \\
(\mathrm{mM})\end{array}$ & $\begin{array}{c}\text { Onset } \\
\text { potential } \\
(\mathrm{mV})\end{array}$ & Performance & $\begin{array}{l}\text { Reference } \\
\text { electrode }\end{array}$ & Ref. \\
\hline $\begin{array}{c}\text { Nanoporous gold } \\
\text { leaves/GCE }\end{array}$ & $0.5 \mathrm{M} \mathrm{H}_{2} \mathrm{SO}_{4}$ & 50 & 10 & 95 & $-1 \mathrm{~mA} / \mathrm{cm}^{2}$ at $c a .-100 \mathrm{mV}$ & SCE & 1 \\
\hline $\mathrm{Au} / \mathrm{Fe} / \mathrm{PVP} / \mathrm{GCE}$ & $0.1 \mathrm{M}$ acetate buffer & 50 & 10 & ca. 280 & -- & $\mathrm{Ag} / \mathrm{AgCl}$ & 2 \\
\hline Polycrystalline gold & $\begin{array}{c}0.1 \mathrm{M} \mathrm{NaOH}^{+} 12.5 \\
\mathrm{mM} \mathrm{I}^{-}\end{array}$ & 100 & 10 & ca. -500 & $-1 \mathrm{~mA} / \mathrm{cm}^{2}$ at $c a .-740 \mathrm{mV}$ & $\begin{array}{c}\mathrm{Ag} / \mathrm{AgCl} / \\
\mathrm{NaCl} \\
\text { saturated }\end{array}$ & 3 \\
\hline Prussian Blue/GCE & $0.1 \mathrm{M} \mathrm{HCl}$ & 10 & 500 & ca. 600 & $-1 \mathrm{~mA} / \mathrm{cm}^{2}$ at $c a .-110 \mathrm{mV}$ & $\mathrm{Ag} / \mathrm{AgCl}$ & 4 \\
\hline $\begin{array}{c}\text { Sand-blasted stainless } \\
\text { steel }\end{array}$ & $0.5 \mathrm{M} \mathrm{NaClO}_{4}$ & 5 & 5 & ca. 50 & -- & SCE & 5 \\
\hline $\begin{array}{c}\mathrm{Pd} \text { on Au rotating-disk } \\
\text { electrode }\end{array}$ & $0.1 \mathrm{M} \mathrm{H}_{2} \mathrm{SO}_{4}$ & 50 & 30 & $\begin{array}{l}\text { ca. } 1000 v s . \\
\text { RHE }\end{array}$ & $\begin{array}{c}-1 \mathrm{~mA} / \mathrm{cm}^{2} \text { at } c a .700 \mathrm{mV} \\
v s . \mathrm{RHE}\end{array}$ & $\mathrm{Ag} / \mathrm{AgCl}$ & 6 \\
\hline $\mathrm{Co}_{3} \mathrm{O}_{4}$ on $\mathrm{Ni}$ foam & $3 \mathrm{M} \mathrm{NaOH}$ & 5 & 600 & -150 & $\begin{array}{c}-110 \mathrm{~mA} / \mathrm{cm}^{2} \text { at } c a .-400 \\
\mathrm{mV}\end{array}$ & $\mathrm{Ag} / \mathrm{AgCl}$ & 7 \\
\hline $\begin{array}{c}\mathrm{Pd} @ \text { nanoporous Au/ } \mathrm{Ni} \\
\text { foam }\end{array}$ & $0.5 \mathrm{M} \mathrm{H}_{2} \mathrm{SO}_{4}$ & 5 & 600 & ca. 500 & $\begin{array}{c}-178 \mathrm{~mA} / \mathrm{cm}^{2} \text { requires } c a . \\
200 \mathrm{mV}\end{array}$ & SCE & 8 \\
\hline$(\mathrm{Co}, \mathrm{Mn})_{3} \mathrm{O}_{4}$ on $\mathrm{Ni}$ foam & $3 \mathrm{M} \mathrm{KOH}$ & 10 & 600 & -- & $\begin{array}{c}-329 \mathrm{~mA} / \mathrm{cm}^{2} \text { at } c a .-400 \\
\mathrm{mV}\end{array}$ & $\mathrm{Ag} / \mathrm{AgCl}$ & 9 \\
\hline$P A M C-900 / G C E$ & $0.1 \mathrm{M} \mathrm{H}_{2} \mathrm{SO}_{4}$ & 10 & 30 & ca. 500 & $-1 \mathrm{~mA} / \mathrm{cm}^{2}$ at ca. $350 \mathrm{mV}$ & $S C E$ & $\begin{array}{l}\text { This } \\
\text { work }\end{array}$ \\
\hline PAMC-900GCE & $0.5 \mathrm{M} \mathrm{H}_{2} \mathrm{SO}_{4}$ & 10 & 30 & ca. 550 & $-1 \mathrm{~mA} / \mathrm{cm}^{2}$ at ca. $395 \mathrm{mV}$ & $S C E$ & $\begin{array}{l}\text { This } \\
\text { work }\end{array}$ \\
\hline$P A M C-900 / G C E$ & $0.1 \mathrm{M} \mathrm{КОН}$ & 10 & 30 & $c a .-120$ & $-1 \mathrm{~mA} / \mathrm{cm}^{2}$ at ca. $-150 \mathrm{mV}$ & $S C E$ & $\begin{array}{l}\text { This } \\
\text { work }\end{array}$ \\
\hline PAMC-900/Ni foam & $3 \mathrm{M} \mathrm{КОН}$ & 10 & 600 & -235 & $-20 \mathrm{~A} / \mathrm{g}$ at ca. $-462 \mathrm{mV}$ & $S C E$ & $\begin{array}{l}\text { This } \\
\text { work }\end{array}$ \\
\hline
\end{tabular}

${ }^{a}$ Please note that because of the differences in electrode preparation and the electrochemical measurement, precise comparison of the HPRR catalytic activities of the different notable materials listed above with one another is difficult. Nevertheless, based on the list of the catalytic activity of the selected materials, we can conclude that the PAMC-900 we prepared possesses higher catalytic performance than many of the materials, including nanoporous gold leaves or Prussian blue. 


\section{References}

1. Yan, X.; Meng, F.; Xie, Y.; Liu, J.; Ding, Y. Direct $\mathrm{N}_{2} \mathrm{H}_{4} / \mathrm{H}_{2} \mathrm{O}_{2}$ Fuel Cells Powered by Nanoporous Gold Leaves. Sci. Rep. 2012, 2, 941.

2. Kim, J.; Gewirth, A. A. Electrocatalysis of Peroxide Reduction by Au-Stabilized, Fe-Containing Poly(vinylpyridine) Films. J. Phys. Chem. B 2005, 109, 9684-9690.

3. Miah, M. R.; Ohsaka, T. Kinetics of Electroreduction of $\mathrm{H}_{2} \mathrm{O}_{2}$ at Gold Electrodes in Iodide-Containing Alkaline Media. J. Electrochem. Soc. 2007, 154, F186-F190.

4. Shaegh, S. A. M.; Nguyen, N.-T.; Ehteshami, S. M. M.; Chan, S. H. A Membraneless Hydrogen Peroxide Fuel Cell using Prussian Blue as Cathode Material. Energy Environ. Sci. 2012, 5, 8225-8228.

5. Patra, S.; Munichandraiah, N. Electrochemical Reduction of Hydrogen Peroxide on Stainless Steel. J. Chem. Sci. 2009, 121, 675-683.

6. Cao, D.; Sun, L.; Wang, G.; Lv, Y.; Zhang, M. Kinetics of Hydrogen Peroxide Electroreduction on Pd Nanoparticles in Acidic Medium. J. Electroanal. Chem. 2008, 621, 31-37.

7. Cao, D.; Chao, J.; Sun, L.; Wang, G. Catalytic Behavior of $\mathrm{Co}_{3} \mathrm{O}_{4}$ in Electroreduction of $\mathrm{H}_{2} \mathrm{O}_{2}$. J. Power Sources 2008, 179, 87-91.

8. Ke, X.; Xu, Y.; Yu, C.; Zhao, J.; Cui, G.; Higgins, D.; Chen, Z.; Li, Q.; Xu, H.; Wu, G. Pd-Decorated Three-Dimensional Nanoporous $\mathrm{Au} / \mathrm{Ni}$ Foam Composite Electrodes for $\mathrm{H}_{2} \mathrm{O}_{2}$ Reduction. J. Mater. Chem. A 2014, 2, 16474-16479.

9. Cheng, K.; Yang, F.; Wang, G.; Yin, J.; Cao, D. Facile Synthesis of Porous (Co, Mn) ${ }_{3} \mathrm{O}_{4}$ Nanowires Freestanding on a Ni Foam and Their Catalytic Performance for $\mathrm{H}_{2} \mathrm{O}_{2}$ Electroreduction. $J$. Mater. Chem. A 2013, 1, 1669-1676. 